\title{
構造体における高強度コンクリートの材料分離と各種性状 PROPERTIES OF HIGH-STRENGTH CONCRETE WITH MATERIAL SEGREGATION IN STRUCTURE
}

\author{
西田 朗*, 斉藤丈士**, 名和豊春***, 山㠃康行**** \\ Akira NISHIDA, Takeshi SAITO, Toyoharu NAWA \\ and Nobuyuki YAMAZAKI
}

\begin{abstract}
In this study, we investigated the influence of material segregations on the behaviors of high-strength concrete. The test results indicate that the mechanical properties of structural concrete more easily influenced by the material segregation.

Material segregation may result in inadequate other performances of the structure using high-strength concrete, besides the degradation of mechanical properties, due to the significant differences in temperature rise and shrinkage. $90 \%$, which is a ratio of actual coarse aggregate area to be the planed one, may be considered as an allowable limit of material segregation. Also, there is no great difference in the performances of structural concrete if the material segregation index of upper layer is not more than $20 \%$.
\end{abstract}

Keywords: high-strength concrete, segregation limit, temperature history, mechanical properties, shrinkage 高強度コンクリート、材料分㕍限界、温度履歴、力学性能、収縮

1. はじめに

筆者らは、既報1) で設計基準強度 $48 \sim 54 \mathrm{~N} / \mathrm{m} \mathrm{m}^{2}$ 程度に相当 する高強度コンクリートを対象として、振動締固めによる施 エを前提とし、・スランプフローの目標值の異なる場合のフ レッシュコンクリートの性状から材料分雇程度を推定する方 法を報告した。

コンクリートの材料分離に関しては、許容される材料分離 の程度を硬化コンクリートの要求と関連させて明確にしてお

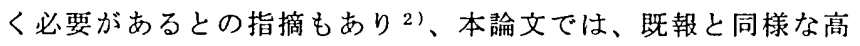
強度コンクリートを対象として構造体中におけるコンクリー トの各種性状と材料分離抵抗性の関係を検討し、さらに材料 分離抵抗性の観点から構造体コンクリートが所要の品質を満 足するための材料分離の指標を提案した結果を述べる。

コンクリートの材料分離は、岩崎によると ${ }^{3)}$ 施工作業中に 起こるものと打込み後において起こるものに分けることがで き、前者は主として粗骨材粒の分離であり、後者は固体粒子の 沈下にともなう水の遊離現象すなわちブリーディングである、 としている。ここで、施工作業中に起こる材料分﨎を粗骨材粒 の分離としているのは、固体粒子の大きさや密度の異なるセ メント、混和材料、細骨材および粗骨材等の粒状固体と水との
混合物であるコンクリートでは、各々の粒子が受ける粘性抵 抗がストークスの法則 ${ }^{31}$ によるとすれば、コンクリート中の 各粒子の分布状態の変化は粒径の 2 乘および粒子の密度に比 例するため、主として粗骨材において起こることになるため である。本論文では、以上の考え方からコンクリートの材料分 離を粗骨材とモルタルの材料分離、細骨材とセメントペース トの材料分離、セメント粒子と水の材料分離に分けて考えた 場合に、粗骨材とモルタルの材料分離に着目した検討が合理 的であるものと判断して検討を行った。また、ブリーディング に関しては、既往の検討 ${ }^{4)}$ ) 5 ) 等で水セメント比 $35 \%$ 以下のコ ンクリートではほとんど発生しないことが指摘されており、 本研究で対象とするコンクリートもこれに該当するため、ブ リーディングについては考虑していない。なお、本論文で使用 したデータの一部は日本建築学会大会で報告したものである ${ }^{61}$ 7)。

\section{2. 実験概 要}

実験は、実機プラントで練り混ぜたコンクリートを模擬試 験体に打ち込み、そのフレッシュコンクリートの性状が構造 体コンクリートの各種性状に及ぼす影響を把握するために以

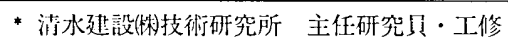

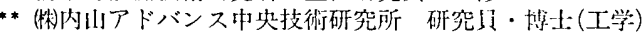

*** 北游道大学大学院工学研究科教授・工博

**** 涪水建设(㑣技術研究所副所長.工修
Senior Research Engineer, Institute of Technology, Shimizu Corporation, M. Eng. Research Engineer, Research Institute of Technology, Uchiyama Advance Co., Ltd., Dr. Eng.

Prof., Graduate School of Hokkaido Univ., Dr. Eng.

Deputy Director, Institute of Technology, Shimizu Corporation, M. Eng. 
下の通り行った。

\section{1 使用材料および調合}

使用材料および調合は既報 ${ }^{1)}$ と同じで、表 $1 、 2$ に示した通

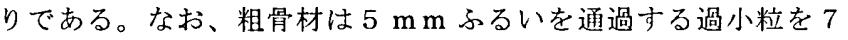
\%、細骨材は $5 \mathrm{~mm}$ ふるいに留まる過大粒を $3 \%$ 含むものをそ のまま使用した。コンクリートの目標スランプフローは、50、 $60 、 70$ および $75 \mathrm{~cm}$ の 4 水淮とし、混和剤の添加量で調整した。

\section{2 実験方法}

コンクリートはレディーミクストコンクリートエ場で練り 混ぜ、実験場までアジテータ車で約 50 分かけて輸送して、打 込みを行った。練混ぜ量は各目標スランプフローのコンク リートとも $2.5 \mathrm{~m}^{3} \times 2$ バッチとし、練混ぜ時間は全材料投入後 90 秒とした。

(1) フレッシュコンクリート

フレッシュコンクリートは、荷卸し時にスランプフロー、 $50 \mathrm{~cm}$ および停止フロー時間、空気量、単位容積質量およびコ ンクリート温度の各項目について測定を行い、目標スランプ フローに達しなかったコンクリートは高性能 AE 減水剂を再添 加し、スランプフローを調整した。この時点で、 $\phi 15 \times 30 \mathrm{~cm}$ の型枠および振動テーブルを用いて既報と同様に材料分離指 数 $S I$ の測定を行い、さらに上部材料分離指数 $s i$ を算出した ${ }^{\prime \prime}$ 。 また、模擬試験体へのコンクリート打込み終了時点で、フレッ シュコンクリートの経時変化を確認するために、再度スラン プフローの測定を行った。

\section{(2) 打込み・締固め}

フレッシュ性状を確認したコンクリートを図 1 に示す 1000 $\times 1000 \times 3150 \mathrm{~mm}$ の柱を模擬した無筋の型枠に打ち込んだ。 打込みは容量 $2.5 \mathrm{~m}^{3}$ のバケットを用いて、1回の打込み高さが おおよそ $1 \mathrm{~m}$ 以内になるようにして行った。打込みごとに、 $40 \mathrm{~mm}$ の高周波棒状バイブレータを下層に先端が入るようにし て $20 \sim 25 \mathrm{~cm}$ 間隔に㨂入して締固めを行った。1 か所での振動 時間は、10 秒程度とした。

\section{（3）温度および硬化コンクリートの測定}

模擬試験体の打込み直後から、図 1 に示すように柱高さ方 向の 500、1500、2600 $\mathrm{mm}$ の各断面において中心部および側面 部（表面から $50 \mathrm{~mm}$ ） の位置でコンクリート温度の測定を行っ た。また、同じく図 1 に示す位置で試験材龄の $3 \sim 4$ 日前に鉛 直方向にコア採取を行い、材龄 $28 、 56 、 91$ 日で気乾単位容積 質量、圧縮強度およびヤング係数の測定、ならびに画像処理に

表 1 使用材料

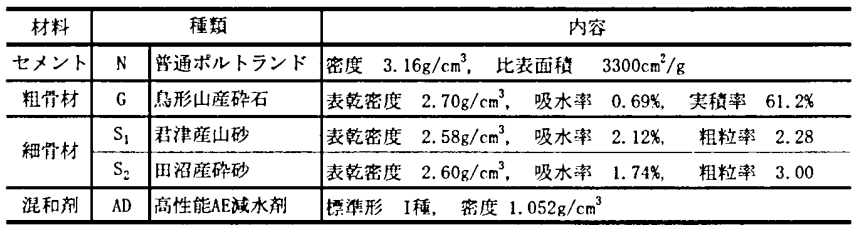

表 2 コンクリートの調合

\begin{tabular}{|c|c|c|c|c|c|c|c|c|c|c|}
\hline \multirow{2}{*}{$\begin{array}{l}W / C \\
(\%) \\
\end{array}$} & \multirow{2}{*}{$\begin{array}{c}\text { 目嫖スランプフロー } \\
(\mathrm{cm})\end{array}$} & \multirow{2}{*}{ 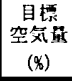 } & \multirow{2}{*}{$\begin{array}{l}\mathrm{s} / \mathrm{a} \\
(\%) \\
\end{array}$} & \multirow{2}{*}{ 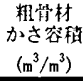 } & \multicolumn{5}{|c|}{ 单位悬 $\left(\mathrm{kg} / \mathrm{m}^{3}\right)$} & \multirow{2}{*}{$\begin{array}{c}\text { AD F } \\
(\mathrm{C} \times \%)\end{array}$} \\
\hline & & & & & $w$ & $\mathrm{C}$ & $\mathrm{s}_{1}$ & $\mathrm{~S}_{2}$ & $G$ & \\
\hline 35.0 & $50 \sim 75$ & 2.0 & 45.1 & 0.558 & 165 & 472 & 503 & 335 & 922 & 1. $15 \sim 1.625$ \\
\hline
\end{tabular}

よるコア端面の粗骨材面積率の測定 ${ }^{4)}$ を行った。さらに、材 齢 6 日で図 1 に示寸位置で水平方向のコア採取を行い $\phi 10 \times$ $30 \mathrm{~cm}$ の供試体を各 3 本成型して材齢 7 日を基長として、コン タクトゲージ法により $20^{\circ} \mathrm{C} 、 60 \% \mathrm{R} . \mathrm{H}$.の環境でコアの長さ変 化試験を実施した。なお、フレッシュコンクリートの性状測定 時に、JIS A 1132 に準じて $\phi 10 \times 20 \mathrm{~cm}$ の供試体採取を行い、 標準羕生した後、材龄 28、56、91 日で圧縮強度およびヤング 係数の测定を行った。表 3 に测定項目および測定方法の一覧 を示す。

\section{3. 実験結果および考察}

(1) フレッシュコンクリート

表 4 にフレッシュ性状の一覧を示す。

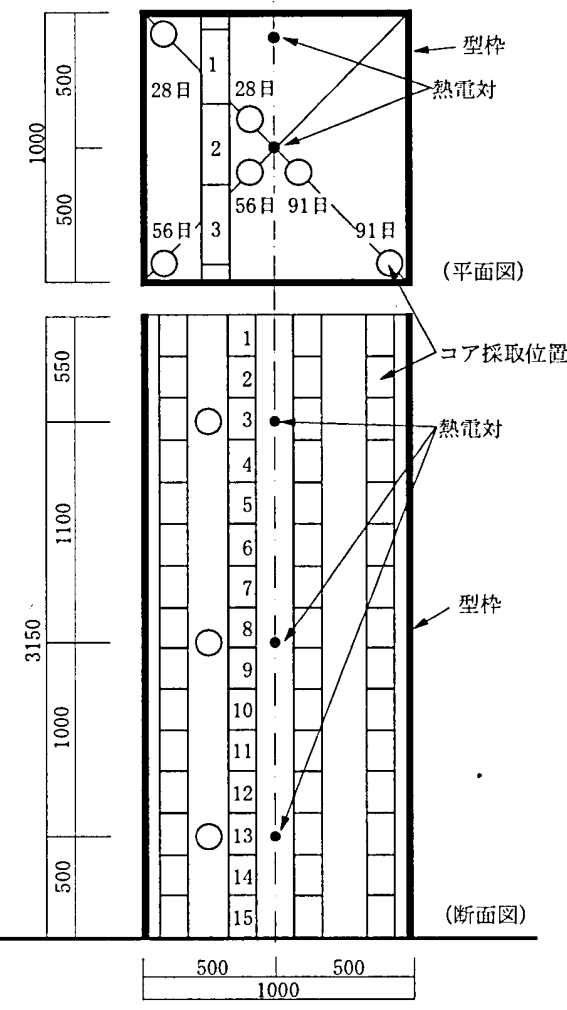

図 1 柱模擬試験体の概要

表 3 测定項目および方法

\begin{tabular}{|c|c|c|}
\hline \multicolumn{2}{|c|}{ 测定项目 } & 测定方法 \\
\hline \multirow{5}{*}{$\begin{array}{l}7 \\
2 \\
y \\
シ \\
z \\
ב \\
ن \\
y \\
y \\
1 \\
1 \\
1\end{array}$} & スランプフロー & JIS A 1150 (50cmおよび停止フロー時間も併せて测定) \\
\hline & 空気童 & JIS A 1128 \\
\hline & 单位容糟贸量 & JIS A 1116 \\
\hline & コンクリート温度 & 棒状温度計による \\
\hline & 材料分謘指数 & 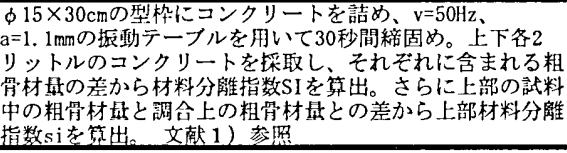 \\
\hline \multicolumn{2}{|c|}{ 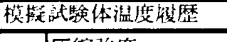 } & T熱電対とテータロカーーを使用 30分毎に測定 \\
\hline \multirow{5}{*}{$\begin{array}{l}\text { 硬 } \\
\text { 华 } \\
\exists \\
\text { y } \\
\text { 多 } \\
y \\
1 \\
1\end{array}$} & 压䌃強度 & JIS A 1107,1108 踹面研糜 コアの高さ補正なし。 \\
\hline & ヤング係数 & JIS A 1149 コンプレッソメーター使用 \\
\hline & 気乾篗位容積䏦量 & $\phi 10 \times 20 \mathrm{~cm}$ 供試体斦期と寸法测定值から算出。 \\
\hline & コア長さ変化 & 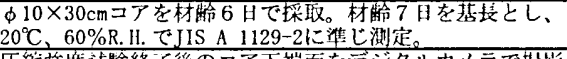 \\
\hline & 粶骨材面皘率 & 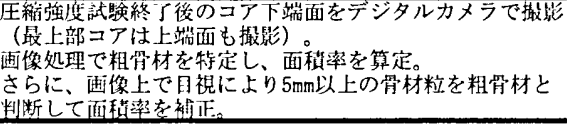 \\
\hline
\end{tabular}


目標スランプフロー $70 \mathrm{~cm}$ および $75 \mathrm{~cm}$ としたコンクリート については荷卸し時、模擬試験体打込み終了時とも目標に近 いスランプフローの值を保持していた。目標 $50 \mathrm{~cm}$ および $60 \mathrm{~cm}$ のコンクリートでは荷卸し時で目標值より $10 \sim 15 \mathrm{~cm}$ 程度スラ ンプフローが小さくなったため、高性能 $\mathrm{AE}$ 減水剤を再添加し てそれぞれ $50.0 \mathrm{~cm} 、 62.0 \mathrm{~cm}$ のスランプフローを得た。しかし、 打込み終了時点では再添加直後に比較して目標 $60 \mathrm{c} \mathrm{m}$ で $14.0 \mathrm{~cm}$ 、同じく $50 \mathrm{~cm}$ で $5.5 \mathrm{~cm}$ 小さくなった。空気量は、1.0〜 $2.3 \%$ で目標値に近い值となった。また、コンクリート温度は、 実験を 7 月に行ったため $31.0 \sim 32.5^{\circ} \mathrm{C}$ となった。

\section{（2）使用したコンクリートの材料分離性評価}

目視による材料分離の観察では、写真 1 に示すように目標 スランプフロー $50 \mathrm{~cm}$ のコンクリートでは材料分離は認められ ず、 $60 \mathrm{~cm}$ でも同様の傾向となった。目標 $70 \mathrm{~cm}$ のコンクリート では表面にモルタルが浮き若干分離ぎみで、同じく $75 \mathrm{~cm}$ のコ ンクリートでは、写真 1 に示すように周辺部にモルタルの先 走りが確認でき、材料分離しているものと判断された。

各スランプフローのコンクリートの上部材料分離指数 $s i$ を表 4 に示す。ここで、既報 ${ }^{1)}$ と同様にスランプフローの值から si 值を推定し、表 4 の実测値との比較をした結果を図 2 に示す。 図には、既報の室内実験による推定値と実測值の対応も示し てある。この図に示すように、本実験における $s i$ 值の実測值は 室内実験に比較して大きく、推定值との対忘も室内実験の場 合とは異なり、実測值は推定值の概略 2 倍程度となった。

上記の傾向の違いについては、以下の考察を行った。

図 3 は、本実験のコンクリートのスランプフローと $50 \mathrm{~cm}$ フ ロー時間の対応を既報の室内実験の結果 1)と併せて示したも のである。この図に示すように、本実験に用いたコンクリート の $50 \mathrm{~cm}$ フロー時間は室内実験の同程度のスランプフローに対 する $50 \mathrm{~cm}$ フロー時間に比較して概ね小さくなった。 $50 \mathrm{~cm}$ フ

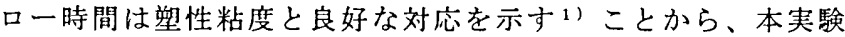
に用いたコンクリートは室内実験のコンクリートより相対的 に粘性が小さいコンクリートであったものと判断される。こ うした違いは、環境温度および練上がりからの経過時間の違 い、試験室ミキサと実機ミキサの練混ぜ性能の違い、あるいは 既往の研究で指摘されている材料の品質変動 ${ }^{8)}$ 等が影響して いるものと考えられる。このうち、練上がりからの経過時間が コンクリートの粘性に及ほす影㸷に関しては、セメントペー ストを用いた確認実験を行った。実験は、コンクリートと同様

表 4 フレッシュコンクリートの性状

\begin{tabular}{|c|c|c|c|c|c|c|c|c|c|}
\hline $\begin{array}{c}\text { 目標 } \\
\text { スランフ } \\
\text { フロー }\end{array}$ & $\begin{array}{c}\mathrm{ADH} \\
(\mathrm{C} \times \%) \\
\end{array}$ & $\begin{array}{c}\text { スランプ } \\
\text { フロー } \\
(\mathrm{cm})\end{array}$ & $\begin{array}{l}50 \mathrm{~cm} \\
\text { 時間 } \\
(\mathrm{sec}) \\
\end{array}$ & $\begin{array}{c}\text { 䧛止時 } \\
\text { 間 } \\
(\mathrm{sec})\end{array} \mid$ & $\begin{array}{c}\text { 空父量 } \\
\\
\text { (\%) }\end{array}$ & $\begin{array}{l}\text { 监位容 } \\
\text { 稙许量 } \\
\left(\mathrm{kg} / \mathrm{m}^{3}\right)\end{array}$ & $\begin{array}{l}\text { C温度 } \\
\left.{ }^{\circ} \mathrm{C}\right)\end{array}$ & \begin{tabular}{c|} 
上部材料 \\
分雜指数 \\
$(s i)$ \\
$(\%)$ \\
$(\%)$
\end{tabular} & 孉考 \\
\hline \multirow{2}{*}{$75 \mathrm{~cm}$} & \multirow{2}{*}{1.625} & 72.0 & 3.5 & 47.3 & 1.1 & 2394 & 31.5 & 81.8 & 荷降し \\
\hline & & 74.5 & 3.7 & 56.0 & - & - & - & - & 打込み後 \\
\hline \multirow{2}{*}{$70 \mathrm{~cm}$} & \multirow{2}{*}{1.325} & 68.5 & 3.2 & 30.6 & 1.0 & 2380 & 31.5 & 42.5 & 荷降し \\
\hline & & 66.5 & 3.6 & 27.8 & - & - & - & - & 打込み後 \\
\hline \multirow{3}{*}{$60 \mathrm{~cm}$} & 1.100 & 51.5 & - & 4.8 & 1.4 & 2367 & 31.0 & - & 荷降し \\
\hline & \multirow{2}{*}{+0.05} & 62.0 & 2.8 & 14.7 & 1.0 & 2371 & 31.0 & 37.4 & 再穂加後 \\
\hline & & 48.0 & - & 6.0 & - & - & - & - & 打込み後 \\
\hline \multirow{3}{*}{$50 \mathrm{~cm}$} & 1.000 & 34.5 & - & 2.4 & 2.3 & 2340 & 32.0 & - & 荷降 L \\
\hline & \multirow{2}{*}{+0.15} & 50.0 & - & 6.8 & 1.8 & 2351 & 32.5 & 23.2 & 再添加後 \\
\hline & & 44.5 & - & 7.0 & - & - & - & - & 打込み後 \\
\hline
\end{tabular}

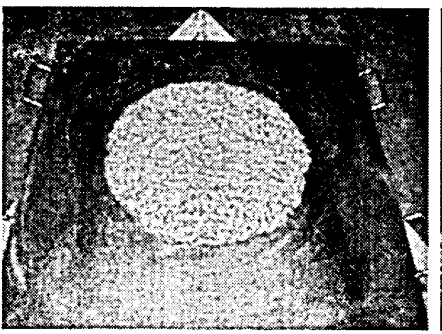

目標フロー $50 \mathrm{~cm}$ (測定値 $50.0 \times 50.0 \mathrm{~cm})$

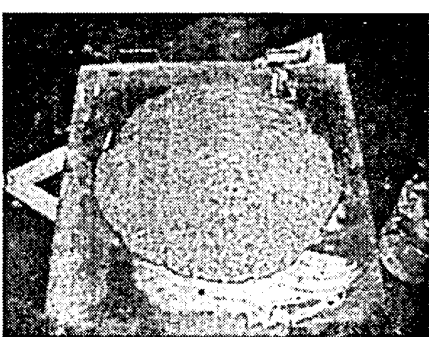

目標フロー $70 \mathrm{~cm}$ （测定値 $70.0 \times 67.0 \mathrm{~cm}$ )

写真 1 スランプフローの状況

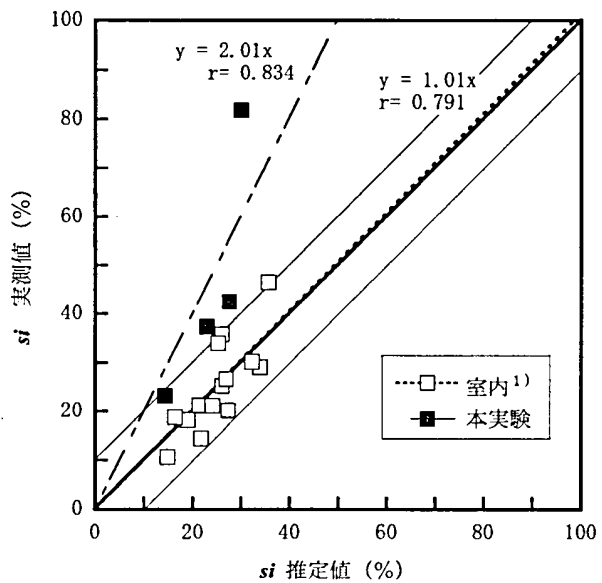

図 2 上部材料分離指数の推定值と実測値の対忘

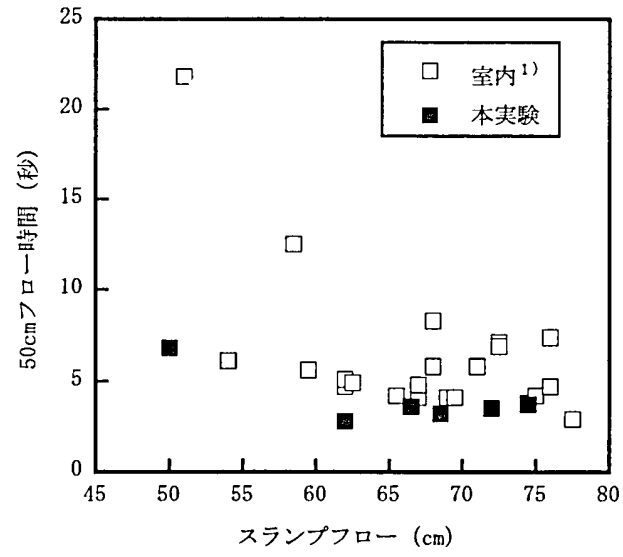

図 3 スランプフローと $50 \mathrm{~cm}$ フロー時間の対応

に水セメント比を $35.0 \%$ とした普通ポルトランドセメント使用 のセメントペースト（高性能 AE 減水剤をセメント量の $0.16 \%$ 添加）をハンドミキサーで 90 秒間練り混ぜ、練上がりから 120 分経過までの粘性をJASS $15 \mathrm{M}-103$ セルフレベリング材の品 質基隻 ${ }^{91}$ に準じて求めたフロー值と振動式粘度計を用いて計 
測した粘度から評価した。フローおよび粘度の測定はそれぞ れの測定時に試料をゴムべらで 60 秒間切り返してから行った。 この結果から、図 4 に示すように時間の経過に伴いフロー值 が若干低下あるいはほぼ一定でも、振動式粘度計による粘度 が低下する傾向を捉えることができた。経過時間に伴う粘性 の低下は既往の研究でも報告されており 10)11，本実験でも、練 上がりから 60 分程度経過したコンクリートを使用したことが、 粘性が小さくなった原因の 1 つと考えることができる。

つぎに、図5 は寺田らのデータ12)を用いて求めたコンク リート中のモルタル降伏值と上部材料分離指数 $s i$ の実測值から 逆算して求めた振動時のモルタル降伏值の対応を示したもの である。モルタル降伏值は、コンクリートのスランプフローか ら（1）式で示すことができ、また、振動時のモルタル降伏值 は、振動時に粗骨材に付着するモルタル量を（2）式とすると、 上部材料分離指数 $s i$ と付着モルタル量には（3）式が成り立つ ことから、上部材料分離指数 $s i$ から求めることができる ${ }^{1 !} 。$

$$
\begin{aligned}
& \tau_{f}=23.59-0.27 S F \\
& M_{S}=\left(0.0162 \tau_{f}{ }^{\prime}+0.0593\right) G \\
& \tau_{f}: \text { モルタル降伏値 }(\mathrm{Pa}) \\
& S F: \text { コンクリートのスランプフロー }(\mathrm{cm}) \\
& M_{S} \quad: \text { 粗骨材Gに付着するモルタル量 }(\mathrm{g}) \\
& \tau_{f}^{\prime}: \text { 振動時のモルタルの降伏值 }(\mathrm{Pa})
\end{aligned}
$$

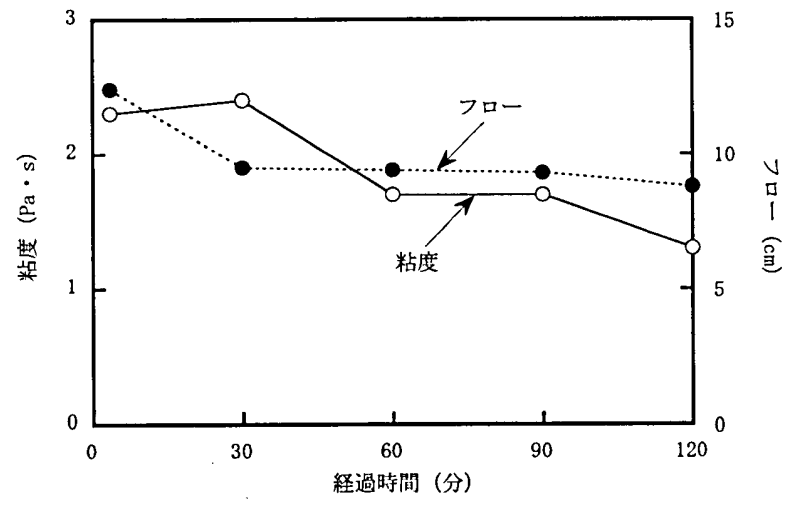

図 4 ペーストでの粘度とフローの経時変化

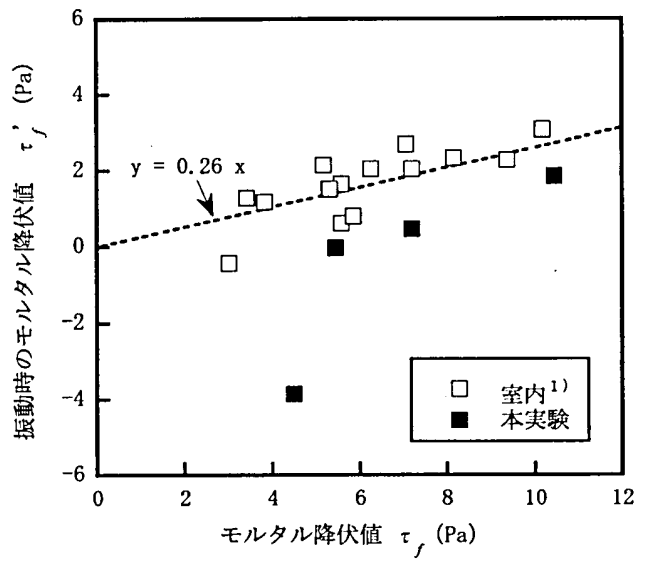

図 5 モルタル降伏值と振動時のモルタル降伏值の対応

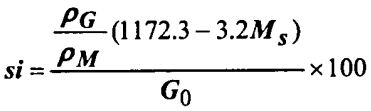

ここに、

$$
\begin{aligned}
& G_{0}: \text { 振動前の上部粗骨材量 }(\mathrm{g}) \\
& \rho_{G}: \text { : 粗骨材の密度 }\left(\mathrm{g} / \mathrm{cm}^{3}\right) \\
& \rho_{M}: \text { : モルタルの密度 }\left(\mathrm{g} / \mathrm{cm}^{3}\right)
\end{aligned}
$$

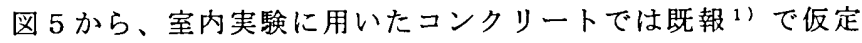
した振動による降伏值の低減率 $74 \%$ （低堿による係数=0.26） はほほ妥当な数值であったことがわかる。これに対して、本実 験に用いたコンクリートは、粘性が小さかったことによる降 伏值の低減がさらに大きかったものと判断される。つまり、振 動によるせん断応力により粗骨材とモルタルの付着が室内実 験に比較して小さくなり、si の実測值が推定值に比較して大き くなったものと考えられる。また、モルタル降伏值が小さいコ ンクリートの一部で、振動時のモルタル降伏值の計算值がマ イナスとなった。これは、締固めを前提としたコンクリートの 材料分離の評価には降伏值だけでなく粘性を考虑した評価が 必要であることを示すものであり、スランプフロー管理のコ ンクリートの場合、モルタル降伏值が小さいときには降伏值 や粘性に応じて振動を与えなければ、構造体に打ち込むコン クリートの材料分離を想定以上に増大させる可能性があるこ とを示唆するものである。

\section{（3）材料分離と模擬試験体の粗骨材面積率}

表 5 は図 1 に示した模擬試験体に打ち込んだ各コンクリー トから採取したコア端面の粗骨材面積率を画像処理によって 求めた結果の概要を示したものである。調合計算上は過大粒 および過小粒を考虑すると $5 \mathrm{~mm}$ 以上の骨材容積が 327 リット ル $/ \mathrm{m}^{3}$ であり、多少のばらつきはあるがいずれのコンクリート も粗骨材面積率の平均值はこれに近い值之なった。しかし、目 標スランプフローが大きいコンクリートほど柱上部の粗骨材 面積率が小さくなり、高さ方向のばらつきが大きくなった。

図 6 は、柱頭位置の高さを０ c m とした各位置における粗骨 材面積率を各コンクリートの平均粗骨材面積率で除した值 （粗骨材面積率比と称す）で示したものである。図に示すよう に、いずれのコンクリートでも測定值を基に粗骨材面積率比 を（4）式で表すことができる。

$$
y=a+b \log (x) \quad(1 \leqq x \leqq 315)
$$

ここに、

$\mathrm{y}:$ 粗骨材面積率比

$\mathbf{x}$ : 高さ位置 $(\mathrm{cm})$ ただし、柱頭 $=0$

$\mathrm{a}, \mathrm{b}:$ 定数

つぎに、各コンクリートの（4）式の係数 $\mathrm{a}, \mathrm{b}$ は図 7 に示す

表 5 粗骨材面積率測定結果の概要

\begin{tabular}{c|c|c|c}
\hline \multirow{2}{*}{\begin{tabular}{c} 
目標スランプフロー 粗骨材面皘率 \\
\cline { 2 - 4 }$(\mathrm{cm})$
\end{tabular}} & \multicolumn{3}{|c}{} \\
\cline { 2 - 4 } & 平均 $(\%)$ & 標準偏差 $(\%)$ & 変動係数 $(\%)$ \\
\hline 75 & 32.7 & 10.3 & 31.5 \\
\hline 70 & 31.5 & 4.7 & 14.8 \\
\hline 60 & 34.0 & 3.3 & 9.6 \\
\hline 50 & 35.4 & 1.9 & 5.5 \\
\hline
\end{tabular}


ように上部材料分雇指数 $s i$ の実測值を用いて一義的に求めるこ とができる。したがって、使用するコンクリートの材料分雖抵 抗性を既報 " で示した上部材料分離指数 $s i$ で定量的に求める ことにより、柱状部材の部材内部における高さ方向の材料分 離の程度を推定することができるものと考えられる。

\section{（4）模擬試験体の温度履歴}

図 8 に、各目標スランプフローのコンクリートの打込みか ら材齢 7 日までの温度履歷を示す。

目標スランプフロー $50 \mathrm{~cm}$ のコンクリートでは、部材側面の 下部でノイズによると思われる若干のデータのばらつきが見 られるが、その他の测定位置では上下方向による温度の差は ほとんどなかった。また、断面側面部の最高温度は上部および

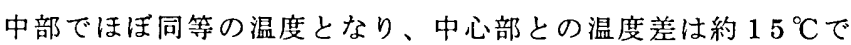
あった。目標スランプフロー $60 \mathrm{~cm}$ および $70 \mathrm{~cm}$ のコンクリー トでは、中心部で上下方向に若干差があるものの $50 \mathrm{~cm}$ のコン
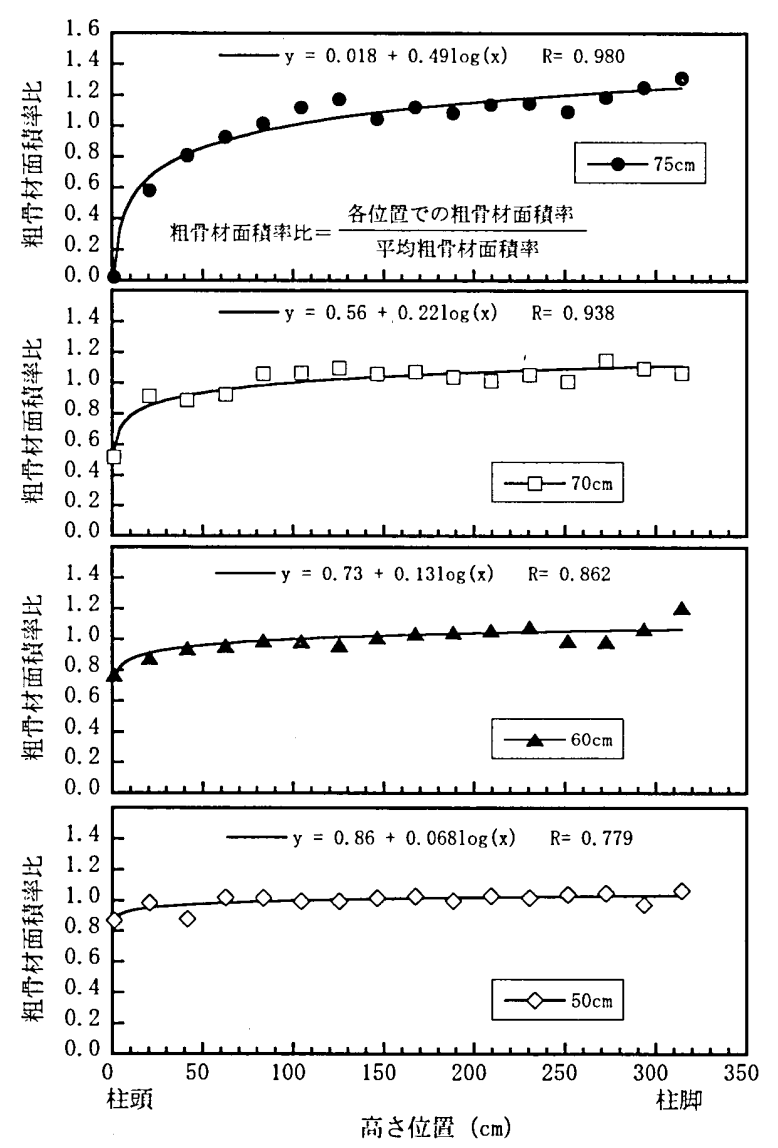

図 6 高さ位置と粗骨材面積率比

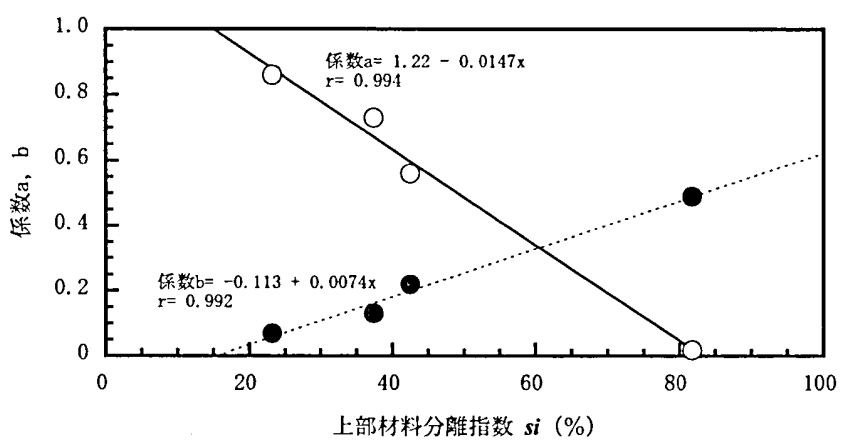

図 7 上部材料分離指数と係数 $\mathrm{a}, \mathrm{b}$ の関係
クリートに近い傾向となった。これに対して、目標スランプフ ロー75 c m のコンクリートでは、中心部最高温度の差が上下方 向で $10.3^{\circ} \mathrm{C}$ とった。同様に側面部でも最高温度の上下方向の 差は $5.8{ }^{\circ} \mathrm{C}$ とった。目標スランプフロー $75 \mathrm{~cm}$ のコンクリー トでは上下方向で粗骨材とモルタルの材料分離により上部の コンクリートでは下部のコンクリートに比較して実際の単位 セメント量が増加したことにより大きな温度差となったもの と考えられる。既往の研究 ${ }^{13)}$ では、普通ポルトランドセメン トを使用した場合に本実験と同程度の寸法の柱部材で単位セ メント量 $10 \mathrm{~kg} / \mathrm{m}^{3}$ の増堿で部材中のコンクリートの最高温度が $1{ }^{\circ} \mathrm{C}$ 程度異なるとの報告があることから、これを本実験の結 果に当てはめると目標スランプフロー $75 \mathrm{~cm}$ のコンクリートで は柱の上部と下部のそれぞれで単位セメント量が $100 \mathrm{~kg} / \mathrm{m}^{3}$ 程 度異なることに相当する結果が得られたことになる。
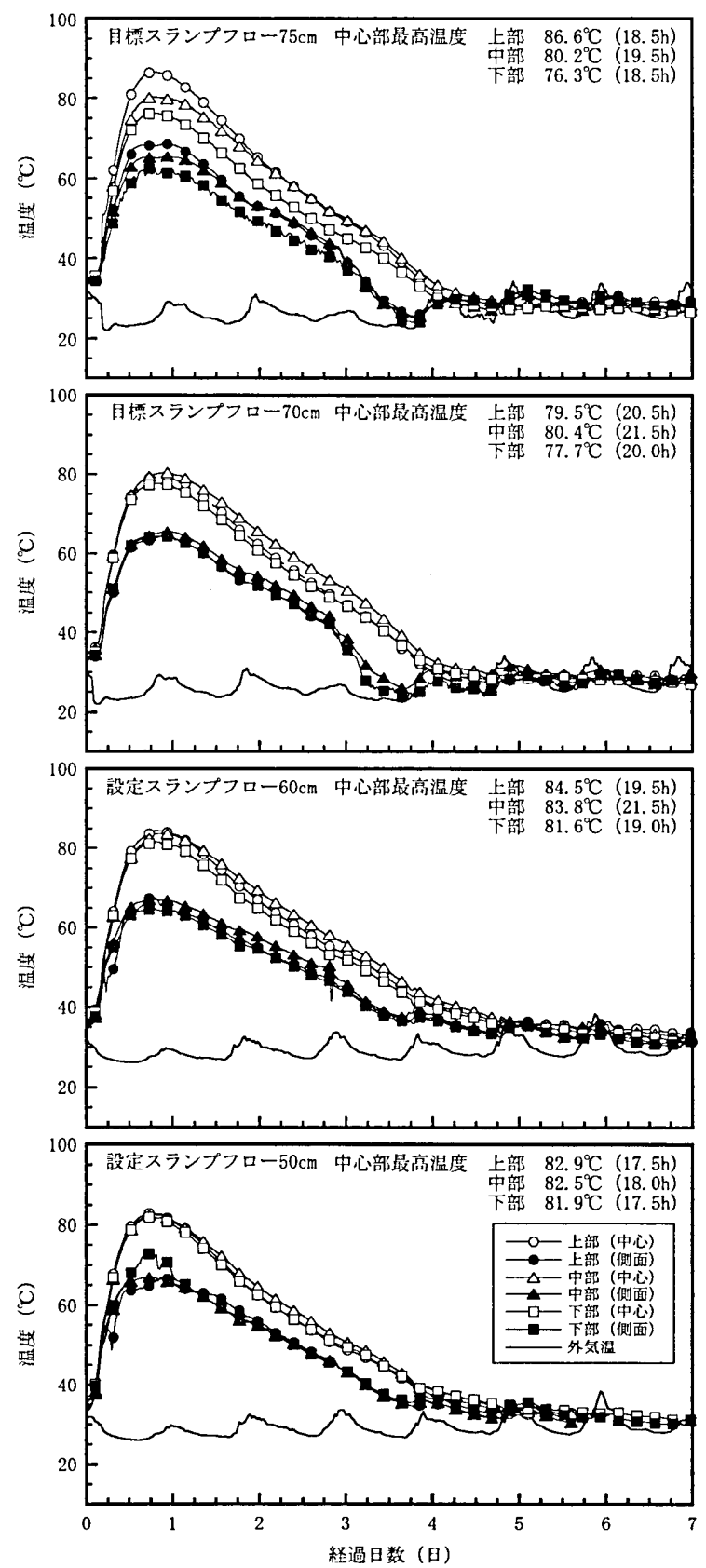

図 8 温度履歷測定結果 

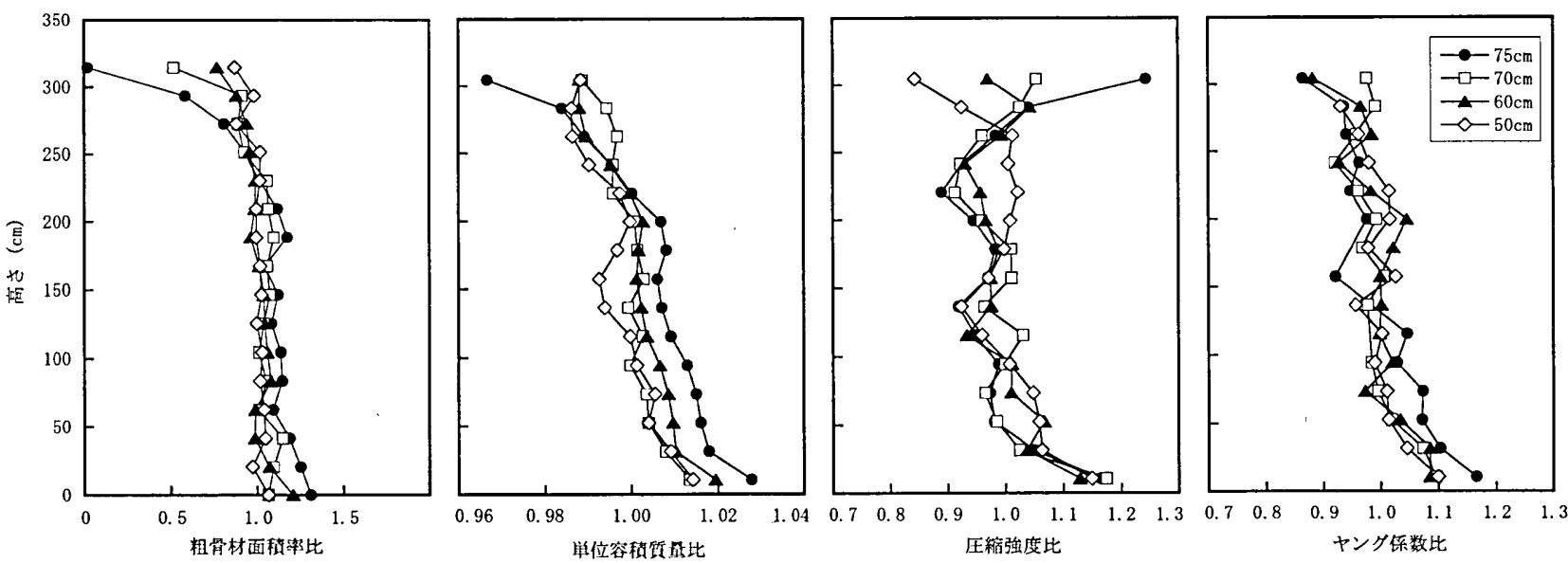

図 9 柱高さ位置と粗骨材面積率比、単位容積質量比、压縮強度比、ヤング係数比の関係

表 6 単位容䅡質量、圧縮強度およびヤング倸数

\begin{tabular}{|c|c|c|c|c|c|c|c|c|c|c|}
\hline \multirow{2}{*}{\multicolumn{2}{|c|}{$\begin{array}{c}\text { 目標スランプフロー } \\
(\mathrm{cm})\end{array}$}} & \multicolumn{3}{|c|}{$\begin{array}{c}\text { 単位容楮暂 } \\
(\mathrm{kg} / \mathrm{e})\end{array}$} & \multicolumn{3}{|c|}{$\begin{array}{c}\text { 圧䧽強度 } \\
\left(\mathrm{N} / \mathrm{mm}^{2}\right)\end{array}$} & \multicolumn{3}{|c|}{$\begin{array}{l}\text { ヤング保数 } \\
\left(\times 10^{4} \mathrm{~N} / \mathrm{mm}^{2}\right)\end{array}$} \\
\hline & & 28 日 & 56 日 & 91日 & 28日 & 56 日 & 91日 & 28 日 & 56 日 & 91日 \\
\hline \multirow{2}{*}{5} & 平均 & 2.43 & 2.42 & 2.42 & 76.7 & 80.8 & 84.2 & 3.97 & 4.09 & 4. 13 \\
\hline & コア平均 & 2.37 & 2.35 & 2.36 & 56.0 & 58.7 & 60.9 & 3.58 & 3.57 & 3.61 \\
\hline \multirow[b]{2}{*}{60} & 標华養生平均 & 2.44 & 2.44 & 2.43 & 71.1 & 77.6 & 81.1 & 4.03 & 4.08 & 4.23 \\
\hline & コア平均 & 2.35 & 2.35 & 2.34 & 54.5 & 57.3 & 58.3 & 3.47 & 3.47 & 3.39 \\
\hline \multirow{2}{*}{70} & 標淮荥生平均 & 2.45 & 2.45 & 2.44 & 77.0 & 83.6 & 87.6 & 3.92 & 4.06 & 4.21 \\
\hline & コア平均 & 2.38 & 2.38 & 2.38 & 59.4 & 61.9 & 63.6 & 3.61 & 3.61 & 3.67 \\
\hline \multirow{2}{*}{75} & 捼準䜤生平均 & 2.49 & 2.48 & 2.48 & 63.3 & 66.2 & 68.3 & 4.42 & 4.41 & 4.60 \\
\hline & コア平均 & 2.40 & 2.40 & 2.40 & 57.5 & 60.9 & 63.9 & 3.48 & 3.74 & 3.69 \\
\hline
\end{tabular}

（5）柱模擬試験体における粗骨材面積率、単位容積筫量、圧 縮強度およびヤング係数

図 9 は各コンクリートの粗骨材面積率の平均值に対する比 率、材齢 91 日に試験を行ったコア供試体の気乾単位容積質量、 圧縮強度およびヤング係数のそれぞれの平均值に対する比率 を高さ方向に示したものである。なお、それぞれの実測值の一 覧を表 6 に示す。

粗骨材面積率比は、（３）で示した通り高さ位置が高くなる ほど小さくなる傾向を示し、その傾向はスランプフローが大 きくなるほど顕著となった。これは、単位容積質量比において もほぼ同様の傾向となり、また、それほど顕著ではないがヤン グ係数比も類似の傾向となった。このことは、単位容積質量お よびヤング係数がコンクリート中に含まれる粗骨材量に依存 することを示し、材料分離により構造体中においてこれらの 均質性が大きく損なわれる可能性があることを示唆している。 一方、圧樎强度比は単位容積質量およびャング係数と異なる 傾向を示した。柱最下部では、圧密によると考えられる影響か ら平均值に比較していずれのコンクリートも $15 \%$ 程度大きな 值となり、概略の傾向としては高さ位置が高くなるとともに 圧縮強度比は渐堿するが、最上部の $50 \mathrm{~cm}$ の節囲では、粗骨材 面積率比の最も大きな $50 \mathrm{~cm}$ のコンクリートの圧縮強度比が最 も小さくなり、粗骨材面積率が小さくなるほど圧縮強度比が 大きくなる結果となった。これは、目標フロー $75 \mathrm{~cm}$ のコンク リートで最も顕著となり、最上部のコア強度は平均值に比較 して $20 \%$ 以上大きな值となった。この傾向は、部材上層部の強 度が最も低く下層部になるにつれて大きくなるという一般の コンクリートを使用した柱部材の強度傾向 ${ }^{14)}$ とは異なり、高 流動コンクリートおよび流動化コンクリートで得られた結果 ${ }^{151}$
16) 17) と一致するものである。

\section{(6) コアの長さ変化}

表 7 は各コンクリートから採取した水平方向コアの試験材 齢 52 週における長さ変化率を示したものである。また、図 10 は目標スランプフロー $75 \mathrm{~cm}$ および $50 \mathrm{~cm}$ のコンクリートの水 平方向コアの長さ変化の経緯を示したものである。

表 7 に示す通り、平均的な長さ変化は設定スランプフロー $50 \mathrm{~cm}$ のコンクリートが最も小さく、続いて $75 \mathrm{~cm}$ となり、目標 スランプフロー $70 \mathrm{~cm}$ および $60 \mathrm{~cm}$ のコンクリートで若干大き めの值となった。しかし、高さ方向での長さ変化率の相違は目 標スランプフロー50〜 70 cm のコンクリートでは平均值士 $5 \%$ 程度であったのに対し、75 c m のコンクリートでは上部と中間 部では長さ変化率の差が $30 \%$ 程度となった。中間部での長さ

表 7 高さ位置における長さ変化率の違い

\begin{tabular}{c|c|c|c|c}
\hline \multirow{2}{*}{ コア位置 } & \multicolumn{4}{|c}{ 長さ変化 $\left(\times 10^{-4}\right)$} \\
\cline { 2 - 5 } & $75 \mathrm{~cm}$ & $70 \mathrm{~cm}$ & $60 \mathrm{~cm}$ & $50 \mathrm{~cm}$ \\
\hline 上部 & $-3.28(1.15)$ & $-3.25(1.06)$ & $-3.21(1.02)$ & $-2.58(0.96)$ \\
\hline 中間部 & $-2.43(0.85)$ & $-2.89(0.94)$ & $-3.00(0.96)$ & $-2.81(1.04)$ \\
\hline 下部 & $-2.83(0.99)$ & $-3.06(1.00)$ & $-3.21(1.02)$ & $-2.68(1.00)$ \\
\hline 平均 & -2.85 & -3.07 & -3.14 & -2.69 \\
\hline \multicolumn{5}{|c|}{ ()内は平均值に对する比率 }
\end{tabular}
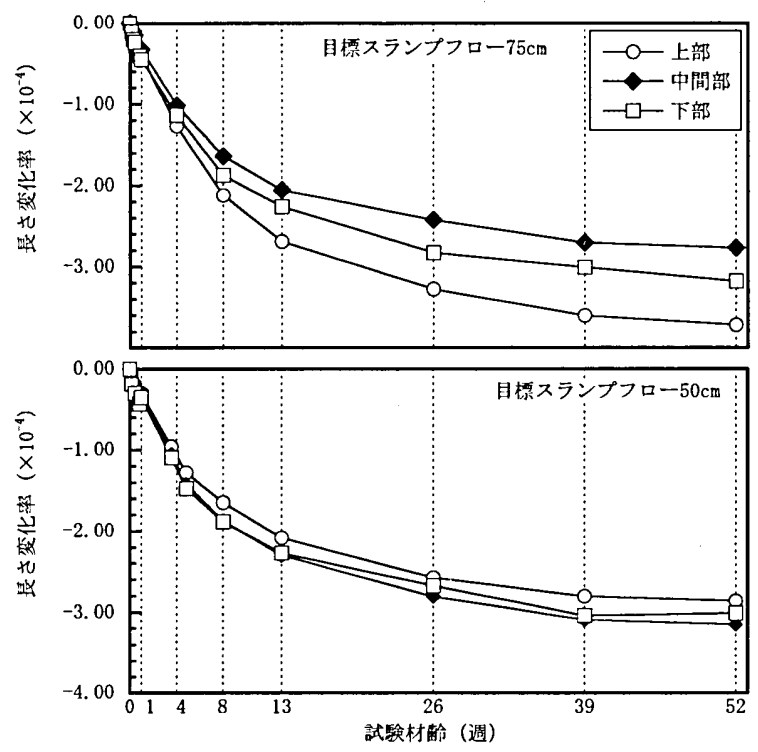

図 10 コアの長さ变化測定結果 
変化が若干小さかったことは、粗骨材面稹率の值がそれほど 大きく変動していないことからもその原因は明確ではないが、 上部の長さ変化が大きくなったことは、図 8 に示した温度上 昇時の最高温度と同様に、材料分﨎による粗骨材の沈降が大 きく影響しているものと考えられる。したがって、材料分㫿は コンクリートの力学性状だけでなく長期的な耐久性に関して も影響を及ぼす可能性があるものと判断される。

\section{4. 材料分離の定量的評価}

図 11 は、（1）式から計算で求めた粗骨材面積率比の推定値 と各材齢でのコア供試体の平均值に対する単位容積質是比、 圧縮強度比およびヤング係数比の関係を示したものである。 この図に示すように推定した粗骨材面積率と、単位容積質量 およびヤング係数の高さ方向の分布は正の相関があり、粗骨 材面積率から単位容積質量およびヤング倸数の傾向を推定す ることは可能と考えられる。しかし、圧縮強度については、粗 骨材面積率比 0.9 付近を境界として、それより小さ場合に負の 相関が認められる。これは材料分﨎により粗骨材とモルタル の構成比が計画した調合と大きく異なったことに起因してお り、ヤング倸数を压縮強度から推定しようとする場合などに 問題が生じる可能性がある。したがって、本実験に用いたコン クリートでは部材中の硬化コンクリートの力学性状の評価に 大きな影響を及ほさない材料分離は、粗骨材面積率が平均の $90 \%$ 程度以上の範囲と考えることができる。本実験で製作し

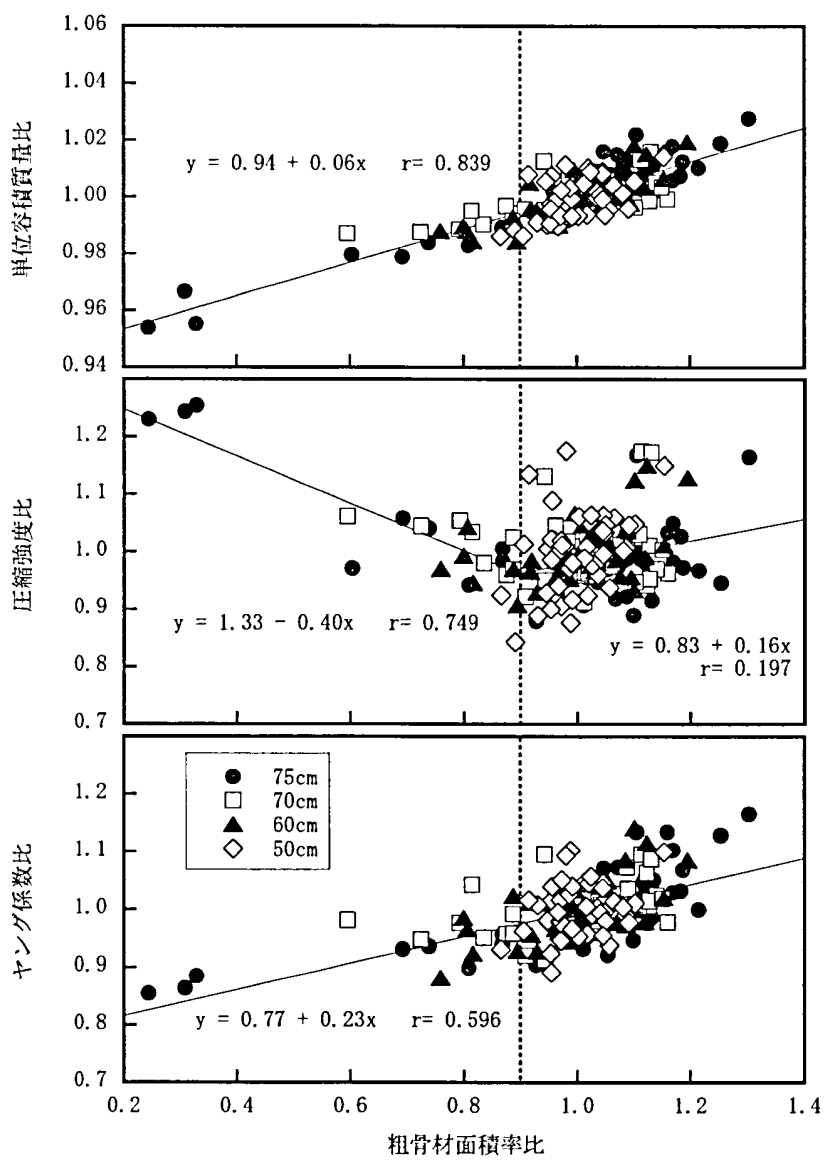

図 11 粗骨材面積率と単位容積質量、压樎強度、 ヤング係数の関保
た柱模擬部材に（4）式を用いて粗骨材面積率比 0.9 以下の位置 を計算すると、設定スランプフロー $75 \mathrm{~cm}$ で上部約 $63 \mathrm{~cm} 、 70 \mathrm{~cm}$ で同じく $35 \mathrm{~cm} 、 60 \mathrm{~cm}$ で $20 \mathrm{~cm} 、 50 \mathrm{~cm}$ で $4 \mathrm{~cm}$ となる。また、最 上部位置（柱頭から $1 \mathrm{~cm}$ の位置）での粗骨材面積率比を 0.90 として、図 4 を用いて上部材料分離指数 $s i$ を求めると $22 \%$ とな り、（4）式から柱脚での粗骨材面積率比は 1.02 となる。部材 内の粗骨材面積率比が $0.90 \sim 1.02$ の範围にあるとすれば、図 11 から材料分㕍に起因する粗骨材面積率比の違いによる単位 容積質量、圧縮強度およびヤング係数の傾向の違いは小さく、 硬化コンクリートの力学性状を評価する際は材料分離を考虑 する必要のない範囲にあるものと考えられる。

一方で、温度上昇量、長さ变化の測定結果から材料分離に対 するコンクリートの性能を判断すると、図 12 に示すように上 下方向の最高温度差は上部材料分雇指数 $s i$ で表すことができ、 $s i$ 值が $20 \%$ 以下では上下方向の最高温度差はほとんどないもの と考えられる。また、長さ変化については、高さ方向のコンク リートの品質の違いは図 13 に示寸ように温度と同様に $s i$ 值で 評価することができる。長さ変化率の差が $0 \%$ に対応する $s i$ 值 は $30.6 \%$ となり、これ以下の上部材料分離指数であれば構造体 に打ち込まれたコンクリートの長さ変化についての品質は均 質なものであると判断することができる。

以上の試算から、上部材料分雇指数を $20 \%$ 程度以下にすれ ば振動締固めを行って施工を行っても、構造体コンクリート としては均質で十分な性能が得られるものと判断される。

\section{5. まとめ}

振動締固めを前提とした高強度コンクリートの材料分離が 硬化性状に及ぼす影響を、実大の模挨試験体を用いて検討し

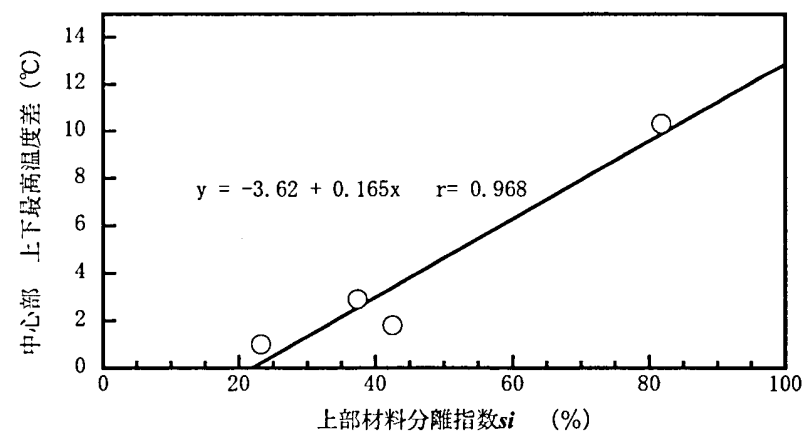

図 12 上部材料分離指数と中心部最高温度差の関係

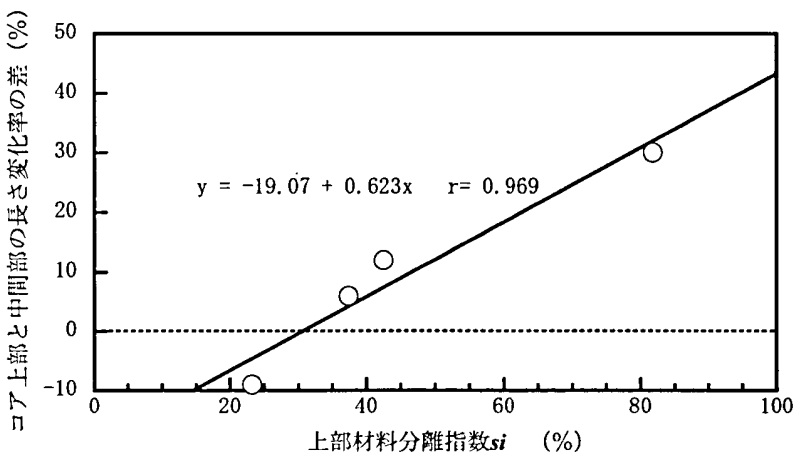

図 13 上部材料分離指数と長さ変化率差の関係 
た。本検討の範囲での知見をまとめると以下の通りとなる。

1）材料分雇を起こしたコンクリートを構造体に打ち込んだ場 合、材料分離を起こした範囲でその力学性状の傾向が健全 なコンクリートと大きく異なる。

2) 材料分離を起こしたコンクリートは、力学性状以外に、温 度上昇や長さ変化の変動が大きくなり、構造体として均質 な性能を保証できない可能性がある。

3）材料分離の許容限界として、粗骨材面積率が平均值の $90 \%$ を得た。本実験に用いたコンクリートでは上部材料分離指 数を $20 \%$ 以下とすることで、均質な構造体コンクリートを 得ることができるものと考えられる。

\section{謝 辞}

本研究を行うに際して、故 奈良禧德 内山アドバンス中央 研究所・所長に多大な協力を戴いた。ご冥福を祈念致します。

\section{参考文献}

1) 西田 朗, 斎藤丈士, 名和豊春, 山嵪庸行：高強度コンクリートの材 料分離性の評価, 日本建築学会構造系論文集, No.585, pp.39 44, 2004.11

2) 黒川善幸, 谷川烡雄, 森 博嗣: フレッシュコンクリートの材料分離 抵抗性に関する一考察, フレッシュコンクリートの流動性と施工性に 関するシンポジウム論文集，日本コンクリート工学協会，pp. $43 \sim 48$, 1996. 4

3) 岩崎剖明: コンクリートの特性, 共立出版, pp. $34 \sim 38,1975$

4）飛坂基夫：低水セメント比コンクリートのフレッシュ状態における物 性，セメント技術年報 $41 ，$ pp. $261 \sim 264 ， 1987$

5) 内田清彦：建築の高性能化を目指して，セメント・コンクリート，No. 605, pp. $28 \sim 38,1997.7$

6) 西田 朗, 小澤貫史, 奈良禧徳, 饭生昌之：高強度コンクリートの材 料分離之構造体における硬化性状（その1 材料分虧指数による評価）， 日本建築学会大会学術講演梗概集 A（関東），pp.269～270，2001.10
7 ）西田 朗, 奈良禧徳, 飯生昌之：高強度コンクリートの材料分離と構 造体における硬化性状（その 2 粗骨材面積率による評価），日本建筑 学会大会学術講演梗概集 A (北陸)，pp.1065 1066, 2002.8

8 ）和美広喜，柳田克巳：高強度コンクリートの流動特性に関する実験的 研究，コンクリート工学論文集，Vol.4，No.1，pp.123～131，1993.1

9 ) 日本建築学会：建築工事標染仕様書・同解説 JASS 15 左官工事, pp.353 355, 1998.1

10）明石外世榯，角田 忍，森本登志也 : Two-Point Workability Testによ るフレッシュコンクリートの物性值測定, フレッシュコンクリートの 物性とその施工への適用に関するシンポジウム論文集, 土木学会, pp.7 $\sim 12,1986.3$

11）李 柱国, 谷川恭雄, 森 博嗣：高流動コンクリートのフレッシュ性 状の経時変化およびチクソトロピーに関する理論的考察, 日本建筑学 会楎造系論文集, No.558, pp.15 22, 2002.8

12）寺田謙一, 佐藤孝一, 山川 勉：高流動コンクリートの各種コンシス テンシー評価方法に関する研究（その9：モルタルのレオロジー試験 (1))，日本建築学会大会学術講演梗概集 A (東海)，pp.495～496，1994.9 13）立部正則，田中伸幸，今井 実：超高強度コンクリートの実用化に関 する実験的研究（その 3 構造体打込み実験)，日本建築学会大会学術 講演梗概集 A（関東），pp.269～270，1988.10

14）日本建築学会：構造体コンクリート強度に関する研究の動向と問題点， pp.82 91, 1987.11

15）葉賀忠昭，柴田辰正，寺西浩司：高流動コンクリートのコンシステン シー評価試験方法（その 5 ：圧縮強度、ヤング係数および粗骨材面積 率の分布)，日本建築学会大会学術講演梗概集 A (北海道)，pp.191 $192,1995.8$

16）寺西浩司，佐藤孝一，柴田辰正：高流動コンクリートのコンシステン シー評価試験方法（その 6 : 圧縮強度およびヤング係数と粗骨材分布 の関係)，日本建築学会大全学術講演梗概集 A (北海道)，pp.193～194, 1995.8

17）島弘, 水口裕之, 和田寿夫, 河野 清：材料分離が流動化コンク リートの硬化後の諸性質に及ほす影響，第6 回コンクリート工学年次 講演会論文集, pp. $5 \sim 8,1984$ 